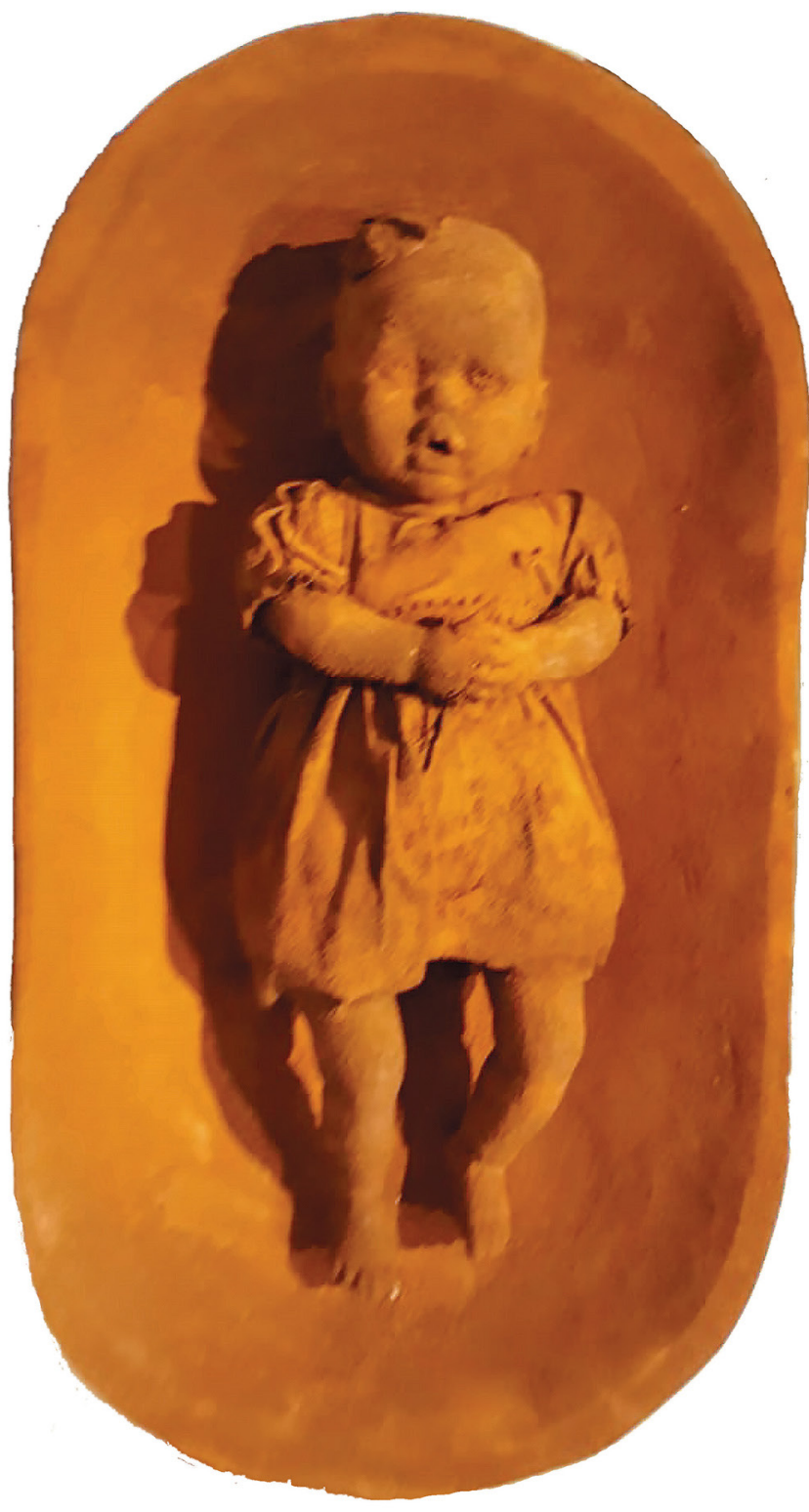




\section{A SOLUÇÃO CONCERTADA APLICADA AO CASO} SAMARCO: ANÁLISE DO DESASTRE DE MARIANA À LUZ DO DIREITO ECONÔMICO

\section{RAFAEL FERREIRA COSTA*}

RESUMO O desastre de Mariana, ocorrido em novembro de 2015, após inúmeras controvérsias jurídicas, recebeu uma "solução concertada", vindo a ser concluída em agosto de 2018. Ela é definida como o arranjo de política econômica efetuado entre entes privados e públicos, instrumentalizado juridicamente, que beneficia os agentes que dele participam, mas prejudica não só os atingidos pelo desastre, como também, o meio ambiente e o país como um todo, a fim de manter as forças reais de poder em detrimento da Constituição Federal. Investiga-se pelo método analítico-substancial os fundamentos jurídicos dessa definição à luz do direito econômico, bem como as suas implicações normativas em relação ao pior desastre socioambiental e socioeconômico do mundo envolvendo barragens de mineração, anterior a Brumadinho (2019).

PALAVRAS-CHAVE desastre de Mariana; solução concertada; Política Nacional da Mineração.

\section{THE CONCERTED SOLUTION TO THE SAMARCO CASE: ANALYSIS OF THE MARIANA DISASTER THROUGH THE LIGHT OF ECONOMIC LAW}

ABSTRACT TThe Mariana disaster, which occurred in November 2015, after numerous legal controversies, received a "concerted solution", which was concluded in August 2018. It is defined as the economic policy arrangement carried out between private and public entities, legally instrumentalized, which benefits the agents who participate in it, but harms not only the affected by the disaster, but also the environment and the country as a whole, in order to maintain the real forces of power at the expense of the Federal Constitution. The legal basis of this definition is investigated by the analytical-substantial method through the light of economic law, as well as its normative implications in relation to the worst socio-environmental and socio-economic disaster in the world involving mining dams, prior to Brumadinho (2019) disaster.

KEYWORDS Mariana disaster; concerted solution; National Mining Policy.

*Doutorando e mestre em Direito Econômico junto à Universidade Federal do Rio Grande do Sul (UFRGS). Advogado.rfcosta.edu@gmail.com . 


\section{Introdução}

$\mathrm{E}$ m cinco de novembro de 20I5, no município de Mariana (estado de Minas Gerais), houve o rompimento da barragem de rejeitos de minério de ferro conhecida como Fundão, pertencente à empresa Samarco Mineração S.A. - uma joint venture entre Vale e BHP Billiton -, em que foram liberados subitamente cerca de 55

1 Não há consenso quanto à quantidade de rejeitos de mineração armazenados e subitamente liberados pelo rompimento da barragem de Fundão em Mariana (MG). Das informações coletadas, foram encontradas variações de 30 a 62 milhões de $\mathrm{m}^{3}$, uma expressiva imprecisão. Foi adotada a aproximação de 55 milhões de $\mathrm{m}^{3}$, com base na declaração de Cristina Serra (2018, p. 19) e da própria Samarco (2016). Por outro lado, veículos da mídia falam em 62 milhões de $\mathrm{m}^{3}$ (DINIZ, 2015), enquanto Natasha Salinas (2016, p. 197) indica 30 milhões de $\mathrm{m}^{3}$.

2 Os rejeitos de mineração atingiram também a Usina Hidrelétrica (UHE) Baguari.

O fornecimento de energia elétrica foi interrompido pois foram atingidos os reservatórios dessas UHE (SALINAS, 2016, p. 216-

217). milhões de metros cúbicos de rejeitos de mineração no vale do Rio Doce (DINIZ, 2015; SALINAS, 20I6, p. I97 e ss.; SERRA, 20I8, p. I9).' Isso gerou uma onda devastadora de mais de 16 milhões de metros cúbicos a percorrer $600 \mathrm{~km}$, com 30\% dela retida pela Usina Hidrelétrica Risoleta Neves (conhecida por "Candonga"). ${ }^{2}$ Os rejeitos tóxicos de mineração atravessaram o território de 39 municípios até alcançarem o oceano Atlântico, seis dias depois, em II de novembro de 2015 (CPRM, 20I5).

Após essa onda, o fluxo de rejeitos continuou por toda a extensão do rio Doce durante dezesseis dias até alcançar a foz do rio Doce, aproximadamente às i5 horas do dia 2I de novembro de 20I5, no Estado do ES. Por consequência disso, I9 pessoas morreram (SERRA, 20I8, p. I5). Segundo Salinas (2016, p. I97), o desastre destruiu o patrimônio arquitetônico e histórico de diversas comunidades locais, desabrigou e desalojou centenas de indivíduos, interrompeu o abastecimento de água de numerosas cidades, destruiu hidrelétricas e obras de infraestrutura, atingiu comunidades indígenas, comprometeu o comércio regional e as atividades produtivas, como pesca e agropecuária, e causou danos ambientais atualmente ainda incalculáveis ao longo de toda a Bacia do Rio Doce - danos que afetarão diversas gerações vindouras (IBAMA, 20I8, p. 24). É tal a extensão e a magnitude dos danos que estes são caracterizados como multidimensionais.

Em meio a inúmeras medidas judiciais, administrativas e humanitárias por diversas entidades públicas, privadas e não governamentais, a fim de não somente apurar a responsabilização, mas também providenciar a recuperação, a remediação, a compensação e a indenização pelos danos multidimensionais causados - ao longo de quase 
três anos (I5 de novembro de 2015 a 25 de junho de 20I8) -, foi celebrado um conjunto de instrumentos jurídicos (Termos de Ajustamento de Conduta) entre as mineradoras Samarco, Vale e BHP Billiton, e várias entidades públicas, estatais e governamentais, que, somado à homologação judicial desses acordos, em agosto de 2018 (SJMG, 20I8), resultou na denominada solução concertada.

Com relação ao problema de pesquisa, visa-se investigar: em que consiste a solução concertada? Quais os seus fundamentos jurídicos à luz do direito econômico? Quais são algumas das implicações derivadas dessa solução concertada e como ela explica a situação passada e atual do pior desastre socioambiental e socioeconômico do mundo envolvendo barragens de mineração, anterior ao desastre de Brumadinho de janeiro de 20I9?

A hipótese de pesquisa é identificar a celebração de um conjunto de medidas de política econômica, instrumentalizadas juridicamente por meio dos Termos de Ajustamento de Conduta (TACs), que reforçaram o status quo do setor de mineração e vêm privilegiar os interesses das próprias mineradoras e dos agentes públicos envolvidos, em prejuízo ao interesse nacional, da defesa do meio ambiente e do povo brasileiro, especialmente das vítimas e dos atingidos. Tais medidas integram o que se designou por solução concertada. Após isso, visa-se extrair algumas implicações dessa solução concertada ao sistema jurídico brasileiro e à política econômica do setor de mineração.

Acerca do vocábulo "desastre", cabe referir que inexiste consenso para a sua conceituação (BUCK, 2005, p. I73-200). Em que pese alguns dos paradigmas definidores do termo "desastre" terem sido agrupados em três categorias por Claude Gilbert, quais sejam: (I) como padrões de abordagem de guerra; (2) como vulnerabilidade social; (3) como incerteza (GILBERT, I998, p. 3-II),3 as discussões científicas relacionadas ao estudo dos desastres pelas ciências sociais e ontológicas (Sociologia, História, Geografia, Economia, entre outras) avançaram significativamente (ALDRICH, 2020).

É reconhecida a compreensão de ter sido um desastre construído por diversos fatores, sobretudo fatores de custo-benefício, não só simbolizando o fim do megaciclo brasileiro de commodities (WANDERLEY et al., 20I6), como também dependente dos conceitos de risco e incerteza, os quais estão ligados a impactos das ações antrópicas
3 Claude Gilbert sintetiza amplamente em três grupos de paradigmas as compreensões sobre o vocábulo "desastre". Considera o paradigma “1) padrões de abordagem de guerra" como reflexo das circunstâncias de seu surgimento: a guerra fria como proteção diante de uma ameaça externa efetiva ou potencial. Já o paradigma "2) desastre como vulnerabilidade social", foi construído a partir do aumento das perturbações nas relações humanas, apesar de obstáculos levantados pela crítica como a eliminação da noção inicial de "agente" do paradigma anterior e as discussões quanto ao significado de vulnerabilidade. Por fim, o paradigma "3) desastre como incerteza" é descrito por três elementos: (i) ameaça à comunidade por um perigo, real ou não, que não pode ser definido através de causas e efeitos; (ii) como consequência da crescente complexidade das comunidades modernas; (iii) perda da capacidade de definir uma situação e de compreender a realidade por meio de estruturas mentais comuns (GILBERT, 1998, p. 3-11). 
ao meio ambiente e seus desdobramentos (ESPINDOLA; NODARI; SANTOS, 20I9, p. I44). O desastre atingiu o seu ápice com o rompimento da barragem de Fundão e permaneceu gerando danos incalculáveis ainda hoje (IBAMA, 20I8, p. 24).

Entretanto, diante da complexidade de um conceito ontológico seguro, será utilizada uma definição legal e deontológica do termo "desastre", bem como de "desastre tecnológico", sendo que para este segundo conceito foi usado o critério relativo à sua origem ou causa primária do agente causador, dispostas, respectivamente, no artigo $2^{\circ}$ e no parágrafo $3^{\circ}$ do artigo $7^{\circ}$, ambos da Instrução Normativa $n^{\circ}$ I, de 24 de agosto de 2OI2, do extinto Ministério da Integração Nacional, ${ }^{4}$ a seguir (BRASIL, 2OI2):

Art. $I^{\circ}$ - Para os efeitos desta Instrução Normativa entende-se como:

I - Desastre: resultado de eventos adversos, naturais ou provocados pelo homem sobre um cenário vulnerável, causando grave perturbação ao funcionamento de uma comunidade ou sociedade envolvendo extensivas perdas e danos humanos, materiais, econômicos ou ambientais, que excede a sua capacidade de lidar com o problema usando meios próprios; [...]

Art. $7^{\circ}[\ldots]$

4 As funções do Ministério da Integração Nacional foram atribuídas ao Ministério do Desenvolvimento Regional pelo inciso IV, do artigo 57, da Lei 13.844, de 18 de junho de 2019, verbis: "Art. 57. Ficam transformados: [...] IV - o Ministério da Integração Nacional e o Ministério das Cidades no Ministério do Desenvolvimento Regional". Portanto são conceitos jurídicolegais ainda válidos no ordenamento jurídico válido, porquanto não foram revogados.

$\int 3^{\circ}$ - São desastres tecnológicos aqueles originados de condições tecnológicas ou industriais, incluindo acidentes, procedimentos perigosos, falhas na infraestrutura ou atividades humanas específicas, que podem implicar em perdas humanas ou outros impactos à saúde, danos ao meio ambiente, à propriedade, interrupção dos serviços e distúrbios sociais e econômicos.

Quanto à metodologia, utiliza-se o método analítico substancial, próprio do direito econômico. Tal método parte do fato originário (político-econômico) para atingir por indução a conclusão jurídica. Após, passa a aplicar as conclusões às hipóteses supervenientes, por meio de dedução (SOUZA, 2002, p. Io6; 2005a, p. I34 e ss.). Funciona em três etapas: (i) observação do fato econômico com métodos da Ciência Econômica (aqui foi utilizada a teoria schumpeteriana); (ii) caracterização da política econômica como "elemento substancial" e ajuste do fato econômico à ideologia, com métodos da Ciência Política; (iii) elaboração das hipóteses e das conclusões jurídicas como "fato jurídico" relativas ao "fato político-econômico", identificando a "norma" (como conteúdo) e a "regra”, em toda a sua extensão (SOUZA, 2005a, p. 134-54). Logo, o conjunto dos Termos de Ajustamento de Conduta celebrados somados à decisão de sua homologação judicial são os fatos econômicos investigados. 
Para fins de coerência e de embasamento científico, é necessário ainda esclarecer os conceitos relativos a: direito econômico, política econômica e ideologia constitucionalmente adotada. Direito econômico é o ramo do Direito que se caracteriza não só como conjunto de normas de conteúdo econômico, tendo por objeto a regulamentação das medidas de política econômica e por sujeito o agente que desta participe, harmonizando interesses individuais e coletivos, dentro da ideologia constitucionalmente adotada (CAMARGO, 20I4, p. 2I), mas também, como direito de síntese em relação ao direito público e privado, posto que essa divisão está ultrapassada (SOUZA, 2005a, p. Iо8).

Por sua vez, política econômica é o conjunto de medidas postas em prática com objetivos econômicos (SOUZA, 2005a, p. 25). Dessa forma, há medidas de política econômica manifestadas tanto pelo poder privado (sobretudo no âmbito da sua liberdade, a exemplo das joint ventures e concentração empresarial, fenômeno oposto à concorrência), quanto pelo poder público (com base nos atos jurídicos que as veiculam, no âmbito da legalidade), bem como a concertação ou a combinação de esforços entre agentes públicos e privados (CAMARGO, 20I4, p. 24).5 Portanto, a Samarco Mineração S.A., como joint venture da Vale e da BHP Billiton do Brasil Ltda., é capaz de efetuar Também diz respeito a um dos elementos-base ao conceito de "solução concertada". medidas de política econômica.

Quanto à “ideologia”, enquanto há o "sentido forte” de ideologia, referindo-se à "falsa consciência”, baseado no pensamento marxista (CAMARGO, 20I0, p. 256-7), o direito econômico vale-se do "sentido fraco" de ideologia, baseado em Karl Mannheim, ao se referir ao pensamento dominante - que independe de valores intrínsecos: ser "bom” ou "mau”, “verdadeiro” ou "falso", "progressista” ou "reacionário” etc. -, opondo-se à "utopia”, pensamento dominado que aspira a ser dominante e independente de valores intrínsecos (CAMARGO, 2010, p. 257).

Por seu turno, a ideologia constitucionalmente adotada é o "sistema de valores plasmado constitucionalmente, que, podendo ser incoerente sob a lógica formal, sem, contudo, deixar de propiciar a informação ao intérprete da conformação a ser dada à ordem jurídica como um todo, e, em especial, à ordem jurídico-econômica" (CAMARGO, 20Io, p. 257-8). Significa que o intérprete levará em conta os valores liberalizantes e socializantes manifestados nos termos jurídico-legais de uma Constituição viva em constante transformação e adaptação ao seu tempo (CLARK; CORREA; NASCIMENTO, 2020, p. 39-45). Com isso, o princípio da economicidade (linha de 
6 Quanto às numerosas críticas à solução concertada, bem como aos fundamentos à sua inconstitucionalidade, conferir: COSTA, 2021.

maior vantagem) é instrumento à solução de conflitos ideológicos (CAMARGO, 20I0, p. 257-8). Assim, na legislação concernente a recursos minerais, relativamente ao instituto econômico da produção, identifica-se a ideologia preservadora dos recursos naturais diante da exploração predatória ou conflitante com os interesses nacionais (SOUZA, 20II, p. 2I-3).

Para haver a fundamentação dessas respostas, em primeiro lugar, serão analisados os elementos principais que compõem a solução concertada para, enfim, propor seu conceito. Em segundo, serão discutidas criticamente algumas das implicações jurídicas desse conceito. ${ }^{6}$ Ao final, serão feitas as considerações conclusivas e a análise pelo método analítico substancial.

Portanto, as questões pertinentes à política econômica - objeto de estudo do Direito Econômico - são, em última análise, pressupostas e concomitantes ao Direito como um todo (CAMARGO, 200I, p. 9I e ss.; SOUZA, 2002, p. 53 e ss.). Esse é o marco teórico empregado.

\section{Os Elementos e a Definição da Solução Concertada}

Afinal, o que significa a solução concertada? Para ser alcançada a resposta a essa questão, é necessário antes o percurso pelos elementos principais que envolveram a construção da solução ao caso, denominada como solução concertada e ao fim definida.

Há quatro elementos identificáveis ao longo da construção do que veio a ser denominada como solução concertada: (i) os instrumentos jurídicos, compostos pelos acordos (Termos de Ajustamento de Conduta) e pela decisão judicial homologatória desses acordos; (ii) a indeterminação dos danos multidimensionais causados, substituídos por um arbitramento consensual alcançando sobretudo direitos indisponíveis; (iii) a concertação política; (iv) a finalidade de manutenção das forças concretas de poder sobre a normatividade da Constituição Federal. A seguir, trataremos de cada um desses elementos.

O primeiro deles é a instrumentalização jurídica. A solução concertada foi alcançada por meio de uma série de instrumentos jurídicos compostos por Termos de 
Ajustamento de Conduta (TACs) sob a disposição normativa constante no parágrafo $6^{\circ}$, do artigo $5^{\circ}$, da Lei 7.347, de 24 de julho de I985 (Lei da Ação Civil Pública), celebrados desde 15 de novembro de 2015 até 25 de junho de 2018 , os quais receberam homologação judicial em agosto de 2018 junto ao processo judicial principal (SJMG, 20I8). A seguir, serão sucintamente descritos esses instrumentos sem análises do contexto fático envolvendo o caso.7

Em I5 de novembro de 20I5, dez dias após o desastre, foi celebrado o Termo de Compromisso Socioambiental Preliminar (TCSAP) ${ }^{8}$ entre o Ministério Público Federal (MPF), o Ministério Público do Estado do Espírito Santo (MPES), Ministério Público do Trabalho do Estado do Espírito Santo (MPT-ES) e a SAMARCO (MPES, 20I5). Ausentes representantes tanto do Ministério Público do Estado de Minas Gerais (MPMG) quanto da sociedade civil e dos entes públicos, assim como ausentes representantes das empresas acionistas Vale S.A. e BHP Billiton do Brasil Ltda., controladoras da Samarco Mineração S.A. De modo geral, o TCSAP estabeleceu obrigações mínimas e emergenciais centrando-se no recurso natural “água” para a sobrevivência da população de somente quatro municípios do ES: Colatina, Linhares, Marilândia e Baixo Guandu. Não foi efetivo para tudo o que se propôs. Em suma, foi instrumento açodado, pois transpareceu se tratar da necessidade de que "algum instrumento deveria ser formalizado, sem se importar com maiores detalhes materiais e formais diante do caso concreto". No dia seguinte, em I6 de novembro de 20I5, foi celebrado o Termo de Compromisso Preliminar (TCP), o qual tratou de uma caução-garantia de R\$ I bilhão pela Samarco, a fim de garantir despesas iniciais com recuperação e reparação dos danos.

Em 2 de março de 20ı6, foi celebrado o Termo de Transação de Ajustamento de Conduta (TTAC), que constitui o principal instrumento jurídico ao caso Samarco, pois expressa formalmente parte da política econômica do setor da mineração, harmonizando interesses públicos e privados. Ele serviu como diretriz maior a possibilitar que os demais instrumentos jurídicos subsequentes passassem a densificar as suas disposições, até a sua consolidação com modificações menores pelo que veio a ser denominado Termo de Ajustamento de Conduta de Governança (adiante, TAC Governança ou TAC GOV), seguida da homologação judicial desses instrumentos em agosto de 20 I8. Houve a presença de representantes de entes políticos e de entes governamentais da
7 Por razões de espaço, é impossível analisar pormenorizadamente todos os instrumentos. Conferir: COSTA, 2021

8 Além do TCSAP (MPES, 2015), o Termo de Compromisso Preliminar (TCP), celebrado em 16 de novembro de 2015 , não será analisado pois tratou especificamente de uma caução-garantia de $\mathrm{R} \$ 1$ bilhão pela Samarco, a fim de garantir despesas iniciais com recuperação e reparação dos danos (MPMG, 2016, p. 9). 
9 União, representada pela Advocacia Geral da União (AGU); Instituto Brasileiro do Meio Ambiente e dos Recursos Naturais Renováveis (IBAMA); Instituto Chico Mendes de Conservação da Biodiversidade (ICMBio); Agência Nacional das Águas (ANA); Departamento Nacional de Produção Mineral (DNPM),

Fundação Nacional do Índio (FUNAI); Estado de Minas Gerais, representado pela Advocacia Geral do Estado de Minas Gerais (MG e AGE-MG, respectivamente), Instituto Estadual de Florestas (IEFMG), Instituto Mineiro de Gestão das Águas (IGAMMG), Fundação Estadual do Meio Ambiente do Estado de Minas Gerais (FEAMMG), Estado do Espírito

Santo, representado

pela Procuradoria Geral do Estado do Espírito Santo (ES e PGE-ES, respectivamente); Instituto Estadual do Meio Ambiente e Recursos Hídricos (IEMAES); Instituto de Defesa Agropecuária e Florestal do Espírito Santo (IDAFES), Agência Estadual de Recursos Hídricos (AGERH-ES). administração direta 9 e da SAMARCO, Vale S.A. e BHP Billiton do Brasil Ltda. (denominadas "ACIONISTAS"), mas a total ausência de representantes do Ministério Público e da Defensoria Pública, além de representantes dos Municípios atingidos.

E, acima de tudo, foi verificada completa ausência da população e da sociedade civil como um todo. Isto é, houve absolutamente "um acordo a portas fechadas" entre entes governamentais e mineradoras devido às decisões de política econômica dos agentes privados e públicos envolvidos de não incluir tais entidades ausentes e seus eventuais representantes. Dito de outro modo, por decisões de política econômica de concertação, o TTAC foi entabulado pelos próprios agentes envolvidos, sem transparência e sem comunicação à sociedade, para atender aos seus interesses, vindo a se tornar público apenas quando da sua assinatura pública. Apesar de posteriormente ter havido a sua anulação judicial pelo MPF, ele permaneceu sendo cumprido pelas mineradoras, "tacitamente válido" e com efeitos práticos.

Em síntese, o TTAC possui pelo menos quatro grandes finalidades: (I) "reinterpretar" ou "ressignificar" os fatos, por meio do "jusrealismo linguístico", de modo a realizar um determinado enquadramento próprio desses fatos para que recebam um tratamento jurídico novo, porém, contrário à lei (contra legem); (2) "elidir" (eximir) a responsabilidade ambiental, cível, administrativa e penal cabível tanto a entes privados quanto públicos, bem como de seus representantes; (3) "organizar" a reparação, mitigação, compensação e indenização dos danos causados à população, ao ambiente, aos estados federados e ao país a parâmetros ínfimos por meio de um fundo financeiro, que tomou a forma de uma fundação de direito privado altamente burocrática e complexa, chamada Fundação Renova. Tal entidade, em síntese estreita, constitui-se como ente independente legalmente instituído que visa a não só cumprir a reparação e a indenização, inter alia, dos danos multidimensionais causados pelo desastre, como também, sobretudo, configurar-se como nova arena administrativa para a solução de conflitos relacionados às consequências do desastre e da atuação dessa mesma entidade, com participação de agentes privados, públicos e de representantes da população; ${ }^{10}(4)$ transformar direitos indisponíveis (difusos, coletivos e individuais homogêneos) em direitos disponíveis transacionáveis por valores arbitrários e pré-determinados (COSTA, 202I). 
Assinado em I8 de janeiro de 20I7, o Termo de Ajustamento Preliminar (“TAP”) marca um novo rumo das negociações entre o protagonismo assumido pelo MPF e as mineradoras: como segunda convenção processual, sinaliza aquiescência tácita dos termos do TTAC, que inclui a criação da Fundação Renova, entre outros termos, bem como a possibilidade de encerramento das ações por meio de negociações (MPF, 20I7). Finalmente, aparenta se preocupar com a determinabilidade dos danos causados pelo rompimento da barragem. Por seu lado, as mineradoras se comprometem com caução-garantia de valores relativamente expressivos. É estabelecido um calendário processual de negociações.

O "Aditivo ao TAP", de I6 de novembro de 2017 (MPF; MPMG, 20I7), complementa o que já vinha sendo feito desde o TTAC e o TAP, no que tange à estrutura e às medidas de recuperação e reparação pelos danos causados, por meio da Fundação Renova e instâncias administrativas em torno dessa entidade, com algumas correções e adaptações, especialmente na parte dos experts e das assessorias técnicas. Formaliza a participação do MPMG, que até então não participava. "

Celebrado em 25 de junho de 20I8, o Termo de Ajustamento de Conduta de Governança, conhecido por TAC Governança ou TAC GOV (MPF et al., 20I8; LOSEKANN, MILANEZ, 2018 , p. 26 e ss.) é o ápice instrumental das convenções processuais desenvolvidas ao longo de quase i8 meses de negociações entre mineradoras, representantes dos entes públicos (União, Estados e autarquias), Ministério Público Federal, conjuntamente do MPMG e MPES, bem como Defensorias Públicas. ${ }^{12}$ Houve, nesse instrumento, o reconhecimento e a formalização das assessorias técnicas que efetivamente mostraram-se benéficos às vítimas e aos atingidos. Porém, as novas instâncias da Fundação Renova aumentaram as exigências burocráticas, esforço e tempo despendido por essas pessoas à propositura, debate e eventual implementação de suas demandas na reformulada grande estrutura de governança da Fundação Renova (SOUZA, T.; CARNEIRO, 20I8, p. 46 e ss.).

Em suma, os instrumentos celebrados podem ser classificados segundo o quadro I, a seguir, contendo as partes compromissárias, data e local da celebração em cada instrumento:
10 A previsão de criação dessa entidade consta no inciso IV, do artigo $5^{\circ}$, do TTAC, verbis "IV - A SAMARCO, a VALE e a BHP instituirão uma Fundação de Direito Privado, com autonomia em relação às instituidoras, com o objetivo de gerir e executar todas as medidas previstas nos PROGRAMAS SOCIOECONOMMICOS E SOCIOAMBIENTAIS". Cuida-se de um caso inédito de entidade de gerência de fundo financeiro de recuperação ambiental (em sentido amplo) de danos originados da atividade minerária no ordenamento jurídico brasileiro. Nesse ângulo, há violação expressa de norma constitucional do art. $225, \int 2^{\circ}$, da Constituição Federal.

11 Há indícios de drástica alteração de rumo das medidas jurídicas conduzidas pelo Ministério Público do

Estado de Minas Gerais (MPMG) diante das mineradoras e das entidades públicas oriunda do fato da destituição de integrantes da equipe original de promotores do MPMC que compuseram a Força Tarefa do Rio Doce (Carlos Eduardo Ferreira Pinto [Coordenador], Marcos Paulo de Souza Miranda e Mauro da Fonseca Ellovitch) ter se dado logo após a assunção do cargo pelo novo Procurador-Geral do Estado de MG, Antonio Tonet, em 5 de dezembro de 2016 , durante o governo do Estado de MG, Fernando Pimentel (PT) (Gı-MG, 2016). 
12 Após celebrar o TCSAP e o TCP em 2015, o MPF veio a celebrar o TAP em janeiro de 2017. Posteriormente, houve o ingresso do MPMG no Aditivo ao TAP, em novembro de 2017 , com convite de ingresso e participação ao MPES, o qual foi acatado pelo órgão capixaba. Com isso, verifica-se protagonismo do MPF nos acordos.
Quadro 1- Principais Termos de Ajustamento de Conduta Celebrados

(TACs do Desastre do Rio Doce)

\begin{tabular}{|lll|}
\hline Instrumento & Partes Compromissárias & $\begin{array}{l}\text { Data e Local da } \\
\text { celebração }\end{array}$ \\
\hline TCSAP & MPES, MPF, MPT-ES; Samarco. & $\begin{array}{c}15 / 11 / 2015, \\
\text { Vitória/ES }\end{array}$ \\
\hline TCP & MPES, MPF; Samarco & $16 / 11 / 2015$, \\
& & BH/MG \\
\hline TTAC & UNIÃO (AGU), IBAMA, ICMBio, ANA, DNPM, FUNAI, & $2 / 3 / 2016$, \\
& MG (AGE-MG), IEF-MG, IGAM-MG, FEAM-MG, ES (PGE- & Brasília/DF \\
& ES), IEMA-ES, IDAF-ES, AGERH-ES; Samarco; Vale e BHP & \\
& Billiton (denominadas “ACIONISTAS"). & \\
\hline TAP & MPF; Samarco, Vale e BHP Billiton. & $18 / 1 / 2017$, \\
& & BH/MG \\
\hline Aditivo ao TAP & MPF, MPMG; Samarco, Vale e BHP Billiton. & $16 / 11 / 2017$, \\
& & BH/MG \\
\hline TAC GOV & MPF, MPMG, MPES, DPU, DPMG, DPES; UNIÃO (AGU), & $25 / 6 / 2018$, \\
& IBAMA, ICMBio, ANA, DNPM, FUNAI, MG (AGE-MG), & BH/MG \\
& IEF-MG, IGAM-MG, FEAM-MG, ES (PGE-ES), IEMA-ES, & \\
& IDAF-ES, AGERH-ES; Samarco, Vale e BHP Billiton (em & \\
& Conjunto, denominadas “EMPRESAS"); Vale e BHP Billiton & \\
(denominadas “ACIONISTAS"). & \\
\hline
\end{tabular}

Fonte: COSTA (2021)

Em 8 agosto de 20I8, houve a homologação judicial do TAC GOV, do TAP e do Aditivo ao TAP (SJMG, 20I8) de forma conjunta, mediante decisão fundada principalmente no caput do art. $3^{\circ}$, bem como no $\int 2^{\circ}$ do art. $3^{\circ}$, ambos da Lei $n^{\circ}$ I3.I4O, de 26 de

13 A Lei $n^{\circ} 13.140 / 2015$, "Art. $3^{\circ}$. Pode ser objeto de mediação o conflito que verse sobre direitos disponíveis ou sobre direitos indisponíveis que admitam transação.

$\int 1^{\circ}[\ldots] ; \int 2^{\circ}$. O consenso das partes envolvendo direitos indisponíveis, mas transigíveis, deve ser homologado em juízo, exigida a oitiva do Ministério Público" (BRASIL, 2015). junho de 2015 ("Lei de Mediação").로 Essa decisão homologatória possui características atípicas eivadas de inconstitucionalidade, além de ser desconforme ao ordenamento jurídico, também não configura medida estruturante (COSTA, 202I).

Inexistiu homologação judicial conforme o ordenamento jurídico porquanto, no aspecto material, os TACs transigiram e regularam direitos indisponíveis (difusos, coletivos e individuais homogêneos) como se direitos disponíveis fossem, mas também, a decisão homologatória surpreendeu as partes ao inovar além dos termos que foram acertados entre os convenentes. Em termos de garantias processuais, não se trata de decisão homologatória regular, nem sentença, pois viola sobretudo o princípio do devido processo legal, além princípio do contraditório e do princípio da vedação de não-surpresa (COSTA, 202I). 
Também não se trata de medida estruturante, entendida dentro do microssistema processual coletivo (DIDIER JR.; ZANETI JR., 20I8, p. 52-6I), em que o processo coletivo é uma espécie de "processo de interesse público” (DIDIER JR.; ZANETI JR., 20I8, p. 37-5I). Embora tenha homologado integralmente o TAC GOV e demais TACs prévios, a decisão judicial entendeu por determinar ressalvas interpretativas/aditivas no Termo Aditivo ao Termo de Ajustamento Preliminar (“Aditivo ao TAP”) e com isso, homologá-lo parcialmente.

O segundo elemento é a indeterminação, nos Acordos, dos danos multidimensionais causados às vítimas e aos afetados, o meio ambiente e ao país como um todo, substituídos por um arbitramento consensual o qual alcançou sobretudo direitos indisponíveis (COSTA, 202I). Dentre os danos multidimensionais podem ser elencados: humanos, ao afetar comunidades indígenas, quilombolas e ribeirinhas, socioeconômicos, criminais, materiais, morais, trabalhistas, cíveis, de política econômica, arquitetônicos e históricos, além de ambientais e ecológicos que perdurarão por um período incalculável às gerações futuras.

A adequada medida de recuperação, reparação, compensação, mitigação e indenização, inter alia, dos danos multidimensionais causados pelo desastre depende, necessariamente, da determinabilidade desses danos efetivos e potenciais, presentes e futuros (COSTA, 202I). Sem isso, tudo o mais são arbitrariedades, cogitações e estimativas abstratas sem base fática concreta. Até hoje não houve ainda determinação completa dos danos decorrentes do desastre, tal a magnitude dos danos. Afora vidas humanas que perderam todo o referencial, especialmente nas comunidades destruídas de Bento Rodrigues, Paracatu de Baixo e Gesteira, comunidades indígenas e quilombolas, pescadores sem possibilidade de exercer seu oficio, entre tantos outros atingidos, a complexidade do ecossistema também é um fator relevantíssimo. Nessa senda, é oportuna a indagação acerca das razões políticas que levam à ausência de conhecimentos prévios das próprias autoridades públicas sobre os elementos que compõem o ecossistema da Bacia do Rio Doce, de um lado, e da ausência de divulgação ou de acesso aos conhecimentos dos agentes privados, de outro. Portanto, como um dos pontos fundamentais dos TACs, a determinabilidade dos danos multidimensionais não foi estabelecida, mas arbitrada propositalmente e acordada pelas partes. 
O terceiro elemento é o arranjo de política econômica entre os agentes privados e os agentes públicos, a configurar uma nítida concertação de política econômica (COSTA, 202I). Tal concertação ocorreu ao longo do período de quase 3 anos e culminou na celebração do TAC GOV em junho de 20I8, o qual foi homologado pelo Poder Judiciário em agosto de 20I8. Ainda que houvesse divergências institucionais internas ao próprio Ministério Público nas instâncias estadual e federal, a partir de 20I7, a nova composição de representantes do MPMG passou a se alinhar ao protagonismo do MPF nas negociações diante das mineradoras em dezenas de reuniões até a formalização de cada um dos TACs seguintes. As divergências da população e de atingidos acabaram sendo institucionalizadas nas alterações organizacionais junto à Fundação Renova sob o TAC GOV.

Por fim, o quarto elemento é a finalidade de manutenção das forças concretas de poder. É consabido que a atividade de mineração deve ser exercida no interesse nacional, em seu aspecto de interesse público ( $\mathbb{I} I^{\circ}$, do art. I76, da Constituição Federal), de forma equilibrada com a defesa do meio ambiente e a recuperação do meio ambiente degradado (inciso VI, do art. I70, combinado com art. 225, caput e $\int 2^{\circ}$, ambos da Constituição Federal). Porém, quando o poder público privilegia os interesses das mineradoras em detrimento da ideologia constitucionalmente adotada, ocorre um desequilíbrio dos direitos fundamentais e da defesa do meio ambiente em prol da exploração mineral (COSTA, 202I).

Apesar de haver argumentos no sentido da defesa da independência do Estado à celebração de acordos em face tanto de órgãos estatais (Ministério Público e Defensoria Pública) quanto da população atingida (ADAMS, 20I9, p. II7-8), trata-se na verdade de uma questão de política de Estado, relativa ao interesse público, bem como dos legitimados para representar tanto o bem comum quanto os interesses e direitos difusos, coletivos e individuais homogêneos, os quais são indisponíveis.

Entretanto, o Estado, mediante os acordos celebrados por seus representantes, no cumprimento do princípio da exploração mineral no interesse nacional, privilegia os interesses das mineradoras em prejuízo do interesse nacional, da defesa do meio ambiente e da ideologia constitucionalmente adotada (SOUZA, 2005a; CAMARGO, 20I4, p. 2I). Dessa maneira, ocorre, na prática, um grave desequilíbrio da proteção dos direitos fundamentais e da defesa do meio ambiente em prol da exploração mineral. 
Há situações em que a atividade da mineração gera graves danos multidimensionais, especialmente diante da ausência da devida prevenção, fiscalização, aplicação normativa e responsabilização por tais danos, tal como o desastre em análise. Além disso, há todo um complexo de danos gerados que necessitam da devida recuperação, reparação, compensação e indenização pelos agentes privados e públicos envolvidos, na medida de sua responsabilidade.

Com isso, se considerarmos o bem comum como subserviente à atividade da mineração - o que enseja abrir mão da defesa do meio ambiente, e, sobretudo, da dignidade humana e dos princípios estruturais da Constituição - então estamos diante de um caso muito mais profundo, implícito e pressuposto ao desastre, que abrange questões sociológicas, culturais, ideológicas, religiosas, políticas, econômicas e jurídicas. Em suma, tanto o contrato social do Brasil quanto a força normativa expressa pela Constituição Federal, nesse setor, desde muito já não tem valor nem eficácia, posto que se trata de uma estrutura estatal submissa ao setor privado.

Toda essa complexidade é relacionada com a "vontade de Constituição" (Wille zu Verfassung) como um intermédio entre as forças políticas e econômicas fáticas em certa sociedade (“Constituição real”) e a ordenação jurídica da realidade ("Constituição jurídica”), em que a última ganha força a partir da “pretensão de eficácia” (HESSE, I99I, p. I5 e ss.). A pretensão de eficácia da Constituição procura imprimir ordem e conformação à realidade política e social (HESSE, I99I, p. I5). Assim, a Constituição adquire força normativa na medida em que realiza essa pretensão de eficácia (HESSE, I99I, p. I6).

Ocorre que, no Caso Samarco, há um conflito entre, de um lado, a ideologia das forças concretas (“Constituição real”), representada pelos interesses particulares das mineradoras e alguns interesses públicos, e, de outro, a ideologia adotada na Constituição Federal (“Constituição jurídica”), a qual tem como seus representantes não apenas os membros de entes públicos, entes autárquicos, órgãos estatais e a sociedade civil como um todo (COSTA, 202I). A primeira ideologia é neoliberalizante, entreguista, e exploradora dos recursos minerais a desconsiderar os direitos fundamentais, a sociedade brasileira e a defesa do meio ambiente como um todo. Interpretam o Estado como um obstáculo, ou ente que exerce um mero papel de gerar "custos" às atividades econômicas (CAMARGO, 2008, p. I5 e ss.): por meio de tributos, laudos 
ambientais e fiscalização precária. A segunda prevê, em suma, a exploração mineral no interesse nacional, feita em equilíbrio com o desenvolvimento nacional, os direitos fundamentais, a defesa do meio ambiente e a soberania nacional.

Portanto, a busca por um equilíbrio entre essas forças configura-se como uma das principais funções da política econômica, a qual é instrumentalizada pelo direito econômico, que toma o "equilíbrio" em relação à política econômica e passa a discipliná-lo. Para Washington Peluso Albino de Souza:

Existe uma espécie de "fetichismo" do "equilíbrio econômico" entre os tecnocratas e os políticos. A concepção veio desde os mercantilistas, com a "balança de trocas", e passou aos conceitos liberais mais puros, pelos quais esse "equilíbrio" se realizava por processos automáticos dentro da sociedade e do mercado, como, por exemplo, pela "lei da oferta e da procura". Invadiu as mentalidades dos estadistas, que procuram por todos os meios estabelecer o equilíbrio orçamentário, o equilíbrio da balança de pagamentos, o equilíbrio econômico geral, enfim, sem definir bem quando e como se chegaria a tais resultados.

Na política econômica posta em prática, pode-se tomar como dado referencial do "equilíbrio" almejado a realização dos objetivos definidos pela ideologia. Tomada a "ideologia do desenvolvimento", por exemplo, o "desequilíbrio" da situação de economia atrasada seria o verdadeiro sentido a ser dado à política econômica para que se atingisse um grau adiantado no qual se pretendesse manter a situação, ou o novo equilíbrio (SOUZA, 2005a, p. I73-I75).

Em outros termos, tomada a ideologia neoliberalizante do setor mineral, ocorreria desequilíbrio em favor do Estado e desfavor para o setor mineral se houvesse, por exemplo, fiscalização no nível necessário à segurança das barragens, apta à proteção das comunidades e do meio ambiente como um todo em padrões internacionais. Por outro lado, se fosse tomada uma ideologia desenvolvimentista a privilegiar as políticas estatais, ocorreria desequilíbrio quando o Estado reduzisse sua atividade ao mínimo necessário para a maior lucratividade do setor privado da mineração.

No âmbito da política econômica, isso se torna mais complexo quando é equacionado o equilíbrio entre dois princípios, a atividade da mineração no interesse nacional e a defesa do meio ambiente, os quais dependem da interpretação acerca do critério identificador da ideologia constitucionalmente adotada. Fica claro, com isso, que a ideologia constitucionalmente adotada se relaciona com a força normativa da constituição. Por fim, ainda é necessário que a ideologia constitucionalmente adotada seja efetivamente posta em prática. 
Um elemento que comprova esse conflito quanto ao equilíbrio entre os princípios referidos é a compreensão do valor de "bem comum”, uma das finalidades essenciais do Estado. Essa finalidade vem sendo materializada na forma de privilégios aos interesses particulares de mineradores, isto é, há a alteração da concepção republicana de "bem comum” para uma concepção privatista de Estado, a considerar o "bem privado" dos agentes envolvidos como forças concretas de poder no país, como superiores aos interesses do povo brasileiro e do meio ambiente brasileiro presente e futuro como um todo.

A partir da aplicação do método analítico substancial aos acordos realizados e à homologação judicial desses acordos, identifica-se não só a destruição criativa de todo um setor de commodities que vinha enfrentando baixa no valor de mercado das suas exportações, como também uma vontade manufaturada (SCHUMPETER, 20I7, p. I2I2, p. 356-8). A seguir, abordaremos esses termos para análise.

De um lado, o capitalismo é um processo evolucionário, uma forma ou método de transformação econômica que não é e nem pode ser estacionário (SCHUMPETER, 20I7, p. II8-2I). O impulso que coloca e mantém em movimento essa dinâmica é dado pelos novos bens de consumo, os novos métodos de produção ou transporte, os novos mercados e as novas formas de organização industrial criadas pela empresa capitalista (SCHUMPETER, 20I7, p. I2I-2). Em essência: inovações. Cada inovação, cada novo processo de produção ou novo produto incorporado à economia supera e destrói o predecessor. Isso gera o processo de destruição criativa (SANDRONI, 20I6).

De outro, o conceito de vontade manufaturada ou vontade fabricada é compreendido de modo que a vontade do povo é a consequência do processo político, não a sua causa. À vista disso, a vontade do povo é manufaturada de modo análogo às campanhas publicitárias, com distrações e com associações favoráveis e desfavoráveis ao subconsciente (SCHUMPETER, 20I7, 356 e ss.). O peso financeiro e a influência político-econômica das mineradoras ocorre tanto nos pleitos eleitorais dos entes políticos das funções executivas e legislativas de todas as esferas (municipal, estadual e federal) quanto na vida de numerosas comunidades e populações em virtude da dependência econômica da atividade mineral, foram determinantes para a construção da solução concertada (SERRA, 20I8, p. 263-78). 
Assim, a solução concertada foi resultante do conjunto de Termos de Ajustamento de Conduta celebrados, somada à homologação judicial desses acordos na ação judicial competente, por meio de um cálculo minucioso em que mormente se preservou as estruturas essenciais do setor de mineração com a proteção quanto à eventual responsabilização de seus agentes envolvidos. Entende-se a solução concertada como: “o arranjo de política econômica entre os poderes privados (mineradoras) e os poderes públicos (entes políticos, órgãos governamentais e de Estado, e seus representantes) instrumentalizado juridicamente (por meio de acordos, entidades jurídicas próprias e de decisões jurídicas) em benefício dos agentes que dele participam, mas em prejuízo não só dos atingidos pelo desastre em diferentes graus, mas também, do meio ambiente e do país como um todo, a fim de manter as forças reais de poder em detrimento da normatividade da Constituição Federal” (COSTA, 202I).

\section{Implicações e Análise Normativa da Solução Concertada}

A solução concertada revela-se como uma consequência da ideologia vigente das instituições brasileiras, de caráter político-econômico, instrumentalizado juridicamente e intrínseco ao desastre do Rio Doce. Dito de outro modo, a partir do rompimento da barragem de Fundão, cujos danos multidimensionais ainda hoje estão indeterminados, veio à tona a política nacional da mineração no Brasil, a qual já era vigente ao tempo do rompimento e assim permaneceu após o desastre mediante a solução concertada.

Configura-se como uma ideologia vigente das instituições brasileiras, porque envolveu ao longo do tempo todos os entes governamentais, públicos e estatais na elaboração de um acordo com as mineradoras que, na prática, realiza uma transação negocial de direitos indisponíveis. Possui caráter político-econômico, porque, se não assume a total falha do Estado brasileiro como um todo ao abdicar da efetivação da normatividade da Constituição Federal, envolve um concerto público-privado, com agentes públicos e políticos, das mais variadas esferas, órgãos e poderes públicos, em busca de uma finalidade comum. É instrumentalizada juridicamente porque foi reconhecida 
como em conformidade à lei, segundo as autoridades competentes, em conflito com as normas constitucionais e com o sentido dado à proteção dos direitos fundamentais e à defesa do meio ambiente. E, por fim, foi intrínseca ao desastre de Mariana, porque mostra a realidade da política nacional do setor mineral dos últimos anos, em que um desastre que eventualmente possa ameaçar as operações do setor da mineração é contornável, a fim de que seja mantido o mesmo status quo dos agentes envolvidos sem maiores considerações com as vítimas, a população brasileira, a defesa do meio ambiente e a efetividade das leis pátrias.

Porém, as consequências da solução concertada não terminam aí; há outros problemas graves, os quais alcançam explícitas violações à Constituição Federal e à ideologia constitucionalmente adotada.

\subsection{A Política Nacional da Mineração}

Antes da exposição de algumas das principais inconstitucionalidades jurídicas da solução concertada, é necessário que sejam feitas considerações acerca da política nacional da mineração, ${ }^{14}$ definida como: "política de controle de um recurso natural estratégico, definindo o papel do Estado e dos atores econômicos particulares na exploração do setor mineral e na apropriação do excedente" (COSTA, 202I).

Ao se tratar a respeito da atividade da mineração como exploração e explotação de recursos naturais minerais, à primeira vista, poderia ocorrer um conflito entre a política econômica (de base extrativo-exportadora) e a política ambiental (de defesa do meio ambiente), sobretudo quando já existe normativa ambiental a partir da Lei $\mathrm{n}^{\circ}$ 6.938, de 3i de agosto de 198I (Lei da Política Nacional do Meio Ambiente). No entanto, configura-se como um conflito aparente de políticas tendo em conta que o Brasil - embora não possua um planejamento setorial nem à mineração nem ao meio ambiente (BERCOVICI, 2003, p. I9I-2I6, CAMARGO, 200I, p. I97-205, p. 255-263, 20I5, p. 2I-80, p. 537-43, SOUZA, 2005b, p. 343-6I) - mantém a manifestação material tanto de uma política nacional da mineração quanto de uma política nacional do meio ambiente, por meio de diversos instrumentos e instituições jurídicos (CAMARGO, 20I6, p. 19-39, p. 69-8I).

Ambas as políticas da mineração e do meio ambiente convivem de forma relativamente harmônica no ordenamento jurídico brasileiro. Exemplo disso é a competência
14 Sinônimos dessa expressão são: "política nacional dos recursos minerais" e "política nacional do setor mineral". 
15 O Código de Mineração sofreu diversas alterações, dentre as relativamente recentes destacam-se as alterações feitas pela Lei $\mathrm{n}^{\circ}$ 9.314, de 14 de novembro de 1996, Lei $n^{\circ}$ 9.827, de 27 de agosto de $1999 \mathrm{e}$ Lei $n^{\circ} 14.066$, de $30 \mathrm{de}$ setembro de 2020 .

6 Ilustrativamente, enquanto está ausente hoje qualquer política nacional de desenvolvimento ao setor da mineração, o período sob a ditadura militar executou planejamento nacional e planejamentos próximos a uma política setorial minerária. Conferir, por exemplo, ter havido, em pleno II Plano Nacional do Desenvolvimento, em que houve aproximação a um plano nacional para a determinação de uma política setorial (MME, 1984, p. 1-8). delimitada e diferenciada entre os ramos de direito minerário e direito ambiental aos órgãos licenciadores e fiscalizadores. De um lado, no âmbito do direito minerário, a atual Agência Nacional de Mineração (ANM) possui competência federal para a regulação e a outorga de direitos (títulos) minerários próprios, denominados por William Freire (2009, p. 59-60 e 78-9I) como Requerimento de Pesquisa, Consentimento para Pesquisa, Consentimento para Lavra, em respeito à legislação minerária específica, sobretudo o Decreto-Lei $n^{\circ}$ 227, de 28 de fevereiro de I967 (Código de Mineração), ${ }^{\text {,5 }}$ O Decreto $n^{\circ}$ 9.406, de I2 de junho de 2018 (Regulamento do Código de Mineração) e a Lei $n^{\circ}$ 6.567, de 24 de setembro de 1978 (Lei do Licenciamento Mineral), entre outras normas. De outro lado, no âmbito do direito ambiental, os órgãos de licenciamento ambiental no âmbito do Estado de Minas Gerais são Conselho Estadual de Política Ambiental (COPAM) e da Fundação Estadual de Meio Ambiente (FEAM) e a Secretaria de Estado de Meio Ambiente e Desenvolvimento Sustentável (SEMAD), a depender não só da organização administrativa de cada estado federado, respeitada a sua autonomia, como também, das disposições da Lei Complementar nº I4O, de 8 de dezembro de 20II, e das normas infralegais competentes.

Assim, adota-se a perspectiva de que - enquanto formalmente inexistente por ausência de planejamento setorial, ${ }^{16}$ contudo materialmente vigente pois instrumentalizada juridicamente - o termo Política Nacional do Setor da Mineração (ou "Política Nacional da Mineração") abrange ambas as políticas de mineração e de defesa do meio ambiente. A atual perspectiva, à luz do Direito Econômico, permite analisar e harmonizar os interesses privados diante dos públicos do setor da mineração, os quais são muitas vezes antagônicos diante do princípio da defesa do meio ambiente. Isso decorre do conflito a partir da realização do interesse nacional (art. I76, $\int I^{\circ}$, da Constituição Federal) por meio da liberdade de iniciativa na exploração e na explotação de minérios (art. I70, caput, da Constituição Federal) e do exercício da soberania nacional (art. I70, inc. I, da Constituição Federal) diante do dever de defesa e de preservação do meio ambiente ecologicamente equilibrado (art. I70, inc. VI c/c art. 225, caput, ambos da Constituição Federal) junto do dever de recuperar o meio ambiente degradado daquele que "explorar" ou explotar minérios (art. 225, \2 $2^{\circ}$, da Constituição Federal).

Portanto, a Política Nacional da Mineração, em seu aspecto econômico, possui o “vetor" da explotação dos recursos minerais no interesse nacional e, em seu aspecto 
ambiental, pelo "vetor" da defesa do meio ambiente, do “desenvolvimento sustentável” e do meio ambiente ecologicamente equilibrado. À vista disso, constitui-se um conflito aparente de políticas, o qual revela, de um lado, uma ineficácia normativa diante das instituições e dos instrumentos jurídicos vigentes e, de outro, uma insuficiência juseconômica - no mínimo - do planejamento setorial para a mineração brasileira.

\subsection{Algumas graves inconstitucionalidades da solução concertada}

Com a homologação do TAC GOV e dos TACs prévios, houve o reconhecimento relativo tanto à legalidade da estrutura inicialmente estabelecida do TTAC quanto da Fundação Renova como entidade legítima a gerenciar as atividades de recuperação e reparação dos danos, inter alia, que antes vinha sendo reconhecida tacitamente. A partir do arbitramento dos valores relativos à recuperação, à remediação, à compensação e à indenização, entre outros, de forma plenamente inconstitucional, sem a devida precisão e determinabilidade do objeto de cada TAC, foi definido um prazo (I5 anos) e um teto de pagamento (aproximadamente R\$ 9 bilhões, com parcelas em 20I6, 2017 e 20I8, respectivamente de $\mathrm{R} \$ 2$ bilhões, $\mathrm{R}$ I,2 bilhão e $\mathrm{R}$ I,2 bilhão, somadas com parcelas anuais de R $\$ 240$ milhões em I5 anos, com variações e ajustes posteriores relativamente menores). ${ }^{.7}$ Assim, o TAC GOV, em reforço ao TTAC, ao tratar, em resumo, de aspectos operacionais da recuperação e da indenização ambiental inter alia, exime, formalmente, a responsabilização das mineradoras, dos agentes e dos entes públicos direta e indiretamente envolvidos no desastre (COSTA, 202I).

Portanto, a solução concertada apresenta graves inconstitucionalidades, as quais serão referidas e sumarizadas a seguir, quais sejam: (i) a indeterminabilidade dos danos multidimensionais; (ii) a ilegalidade da Fundação Renova; (iii) a questão da representatividade (in)adequada das vítimas e dos atingidos junto aos TACs; (iv) transação de direitos indisponíveis por meio do dispositivo "direitos indisponíveis, mas transigíveis" (COSTA, 202I). A primeira delas é relativa à indeterminabilidade dos danos multidimensionais. Por ter natureza de negócio jurídico, o TAC deve respeitar os elementos de existência e os requisitos de validade do negócio jurídico, conforme o art. IO4, do CC, quais sejam: (a) forma prescrita ou não vedada em lei; (b) capacidade das partes (inclusive legitimidade); (c) a possibilidade e a licitude do objeto (NERY JR., 20I4, p. 500).
17 No TTAC, cláusulas 226 e 232 , somam-se valores não computados no cálculo, tal como R $\$ 500$ milhões para saneamento dos Municípios, entre diversos outros aportes. 
Com relação ao objeto de direito material, é necessário considerar a questão da licitude, da possibilidade e da determinabilidade do objeto da prestação, de forma que, na ausência de uma dessas características, ou seja, se o objeto for ilícito, impossível ou indeterminável, o negócio será nulo consoante entendimento de Pontes de Miranda (20I2, p. 3 e ss.) e Marcos Bernardes de Mello (apud NERY JR., 20I4, p. 5OI-502). Portanto, a licitude de negócios jurídicos requer que haja a precisão e a determinabilidade de seu objeto. Diante da impossibilidade da determinação específica dos danos multidimensionais, houve descumprimento da possibilidade e licitude do objeto (item "c" supra), requisito de existência do negócio jurídico. Por consequência, trata-se de negócio jurídico nulo, posto que ilegal.

A segunda tange à ilegalidade da fundação de direito privado, denominada nos acordos como Fundação Renova. Conforme referido acima, a Fundação Renova constitui-se de um fundo financeiro ou fundo de indenização configurado juridicamente na forma de uma fundação de direito privado - como nova arena de conflitos e discussão, muito longe das empresas, do governo e dos órgãos públicos e até eventualmente da jurisdição brasileira heterocompositiva, porque prioriza uma "autocomposição de adesão" (COSTA, 202I). Apesar de ainda permanecer atuante hoje, esse tipo de "construção jurídica" não recebe a necessária guarida pelo ordenamento jurídico pátrio.

A terceira é sobre a questão da representatividade (in)adequada das vítimas e dos atingidos junto aos TACs. Cabe menção desse tópico porque o requisito da representatividade adequada, disposto no inciso I, do artigo $5^{\circ}$ da Lei $n^{\circ} 7 \cdot 347$, de 24 de julho de I985 (Lei da Ação Civil Pública), visa garantir que o legitimado extraordinário represente de forma fidedigna e com qualidade os interesses difusos, coletivos e individuais envolvidos no caso (entre esses legitimados extraordinários estão o Ministério Público, em seus âmbitos estadual e federal, e as Defensorias Públicas, em seus âmbitos estadual e federal). Em suma, houve um abuso dessa posição processual pelos órgãos estatais a partir do momento que passaram a aceitar não só a continuidade das atividades da Fundação Renova, como também, arbitraram e efetivaram ao longo dos acordos uma transação de direitos indisponíveis com as mineradoras, causadoras do Desastre, sem permissão jurídico-legal específica (COSTA, 202I).

Por fim, a quarta e mais importante alcança a transação de direitos indisponíveis por meio da inclusão de um novo dispositivo oriundo da Lei $n^{\circ}$ I3.I40, de 26 de junho 
de 2015 ("Lei de Mediação"). Esse dispositivo contém o trecho “direitos indisponíveis, mas transigíveis", o qual faz referência não apenas ao aspecto material - pois há norma proibitiva de negociação de direitos indisponíveis - mas também, ao aspecto formal e processual, porquanto os dispositivos constantes no parágrafo $2^{\circ}$ e no caput do artigo $3^{\circ}$, da Lei n I3.I40, de 26 de junho de 2015 (“Lei de Mediação"), são inconstitucionais (COSTA, 202I).

Assim, a decisão de homologação judicial dos acordos, por ter adotado homologação de medida inconstitucional, além de ter desconsiderado discussões entre o Ministério Público e grupo de trabalho especialmente formado para esse fim, o qual era composto por representantes de movimentos sociais e grupos acadêmicos envolvidos com o caso visando a um acordo mais próximo das necessidades dos atingidos e ter vedado, em suma, a contratação de assessorias técnicas cujas entidades/membros tenham (a) qualquer vinculação/filiação, direta ou indireta, com partidos políticos ou atividades político-partidárias, (b) vínculo de subordinação com movimentos sociais ou ONGs atuantes na área do desastre de Mariana ou (c) vínculo de subordinação com entidades religiosas configura-se como medida inconstitucional e não classificável dentro das estruturas do ordenamento jurídico brasileiro (COSTA, 202I).

\subsection{Análise Crítica pelo Método Analítico Substancial}

O setor mineral brasileiro, ao priorizar o mercado externo (exportações), detém relevante peso macroeconômico na política econômica brasileira, não só na balança comercial nacional e nos reflexos do PIB brasileiro, mas também, na influência político-econômica que exerce sobre um conjunto de instituições republicanas: desde os órgãos ambientais de fiscalização e os representantes da função Executiva até deputados e senadores, como representantes da função Legislativa, a fim de adaptar as estruturas institucionais brasileiras aos seus interesses particulares (SERRA, 2018, p. 263-278).

Desde a ideologia adotada pela Constituição Federal de ı988, a qual determinou o equilíbrio entre os interesses nacionais na atividade de mineração e a defesa do meio ambiente e que "tem por fim assegurar a todos existência digna, conforme os ditames da justiça social”, podemos constatar que essa ideologia constitucionalmente adotada não é manifestada na realidade, em que os interesses particulares do setor mineral se sobrepõem tanto aos interesses nacionais (na forma de interesse público) quanto à 
defesa do meio ambiente. Por consequência direta, há um enfraquecimento da força normativa da Constituição ao privilegiar os fatores concretos de poder em detrimento da ordem jurídica e dos fatores jurídicos e de organização desses poderes a determinadas finalidades, tal como o desenvolvimento nacional, entre outras, inclusive às dispostas no art. $3^{\circ}$ da Constituição Federal.

Assim, o caso Samarco mostra-se emblemático porque demonstra parte da manifestação dos fatores concretos de poder político-econômico no Brasil, os quais estão "dentro" do Estado e da ideologia constitucionalmente adotada e detêm o poder de "escolher" as medidas a serem tomadas para a recuperação, a reparação, a compensação, a indenização e a mitigação de danos decorrentes de um rompimento de barragem de rejeitos de mineração, cujos riscos já eram antevistos. Tais manifestações de poder ocorrem conforme a sua ideologia de interesses particulares das mineradoras e afronta a ideologia constitucionalmente adotada, numa comprovação de possível quebra do pacto político-jurídico brasileiro: enquanto a Constituição Econômica e a legislação infraconstitucional determinam uma série de direitos e deveres aos seus cidadãos e aos agentes públicos (representantes do poder estatal), determinados agentes privados moldam as instituições e as leis para atender aos seus próprios interesses. Nesse sentido, após o desastre de grandes proporções (matando iو pessoas e afetando a vida de cerca de 800.000 outras, o qual destruiu um inteiro ecossistema da Bacia do Rio Doce), constatamos que de fato nada mudou na política econômica do setor mineral, tamanho é o poder concreto exercido por esses agentes privados sobre os interesses públicos.

\section{Considerações Conclusivas}

Em conclusão, a definição de solução concertada colaborou para desvelar a política nacional da mineração, já vigente ao tempo do Desastre de Mariana. Essa solução procurou manter o status quo no âmago do desastre da barragem de Fundão (ou Desastre do Rio Doce). Por isso, a hipótese de pesquisa foi confirmada. Para se chegar a essa conclusão, foram analisados os elementos do que se denominou solução concertada.

A partir dessa análise, foi feito o cotejo entre o conceito de solução concertada, a Constituição Federal e a ideologia constitucionalmente adotada por meio do método 
analítico substancial, com análise normativa de algumas das implicações da solução concertada.

Por seu lado, as empresas mineradoras, desde a ocorrência do Desastre até a conclusão da solução concertada, jamais assumiram a responsabilidade pelo rompimento da barragem, mas apenas a obrigação muito restrita e convencionada de recuperar, reparar, compensar e indenizar os atingidos e o meio ambiente, por meio das diversas instâncias da Fundação Renova. Ademais, foi a duras penas que as autoridades públicas chegaram a acordos cujos valores de indenização são pífios se comparados com o lucro obtido pela extração dos recursos naturais brasileiros. Para quem já explota recursos minerais há 33 anos, mostra-se algo brutalmente benéfico. Com isso, constata-se uma grave externalidade negativa que foi "socializada” para o meio ambiente, às vítimas e para a sociedade brasileira como um todo.

Nesse sentido, apesar de terem sido formalizados acordos (TACs) supostamente dotados de juridicidade, eles trazem uma aparência de legalidade para legitimar uma prática violadora, pelo setor mineral, da ideologia adotada na Constituição Federal de I988, em especial pela Samarco e suas acionistas controladoras, em pleno acordo com o setor público e órgãos de Estado. Há fatores concretos e reais de poder que submetem a política nacional da mineração aos seus interesses privados, a contrariar a ideologia disposta na Constituição Federal. Isso configura uma grave violação consentida por praticamente todos os agentes envolvidos das estruturas de Estado. Para essa conclusão, foi suficiente analisar a diferença entre a ideologia constitucionalmente adotada e a ideologia efetivamente praticada (privilegiando os interesses privados do setor mineral como fatores reais de poder) e, ao ser privilegiada a segunda, a força normativa da Constituição é gravemente enfraquecida.

A organização político-institucional do Estado brasileiro, cujas características principais expressam a política econômica do Estado e das mineradoras, incluindo o papel político do Judiciário e de seus órgãos de Estado, os quais, em suma, apesar da propaganda privada (green washing) e pública, relativamente aos esforços engendrados e aos resultados alcançados, produzem, de forma concreta, um ínfimo grau de reparação humana e ambiental pelos danos causados, comparativamente aos lucros obtidos pelas mineradoras. Com isso, acaba-se por privilegiar, ao fim e ao cabo, os interesses econômicos privados na exploração das riquezas minerais com insignificante 
responsabilização e indenização pelos danos causados desse Desastre. Não que haja contrariedade à exploração econômica das riquezas minerais nacionais, mas que essa exploração seja de acordo com a eficácia dos preceitos constitucionais econômicos e ambientais (sobretudo, artigos I70, caput e inc. VI; art. I76, parágrafo Iº e art. 225, parágrafos $I^{\circ}, 2^{\circ}$ e $3^{\circ}$, todos da Constituição Federal).

Portanto, é diante desse gravíssimo quadro que se fez necessário o presente artigo, não apenas para mencionar inconstitucionalidades e desvelar elementos da chamada política nacional da mineração aplicada ao caso Samarco, como também apontar caminhos possíveis de diagnóstico e de solução reparatória integral e de responsabilização pública e privada consoante os princípios e regras constitucionais do Estado brasileiro contemporâneo.

Por fim, em que pese a condescendência do Estado brasileiro diante de gravíssimas infrações, violações, danos e crimes ambientais contra a sua população, contra as suas riquezas ambientais e contra a sua soberania nacional, a pesquisa procura apontar caminhos para maiores aprofundamentos em direção ao desenvolvimento nacional e às finalidades do Estado brasileiro. O desastre do Rio Doce é análogo à existência de, em pleno estado nazista, um proprietário do campo de concentração ter apenas um custo a pagar ao usar o gás Zyklon-B para matar contingentes de pessoas inocentes e destruir o meio ambiente enquanto efetua a exploração das riquezas naturais de determinado local conquistado com o consentimento dos agentes públicos e das autoridades locais, regionais e nacionais. Em última análise, pode-se perguntar: será que o Brasil pertence aos brasileiros ou às entidades que, de modo impune, exploram sua população, seusrecursos e seu meio ambiente? 


\section{Referências}

ADAMS, Luis Inácio Lucena et al. Saindo da Lama: a atuação interfederativa concertada como melhor alternativa para solução dos problemas decorrentes do desastre de Mariana. Belo Horizonte: Fórum, 2019.

ALDRICH, Daniel P. The Need for Comparative Research in Disaster Studies: Developing Broader Theories from Research. In: ANDHARIA, J. (Ed.). Disaster Studies: Exploring Intersectionalities in Disaster Discourse. Singapore: Springer Nature Pte Ltd., 2020.

BERCOVICI, Gilberto. Desigualdades Regionais, Estado e Constituição. São Paulo: Max Limonad, 2003.

BRASIL. Decreto-Lei $n^{\circ}$ 227, de 28 de fevereiro de 1967 (Código de Mineração). Dá nova redação ao Decreto-lei $n^{\circ}$ I.985, de 29 de janeiro de I940. (Código de Minas). Diário Oficial da União, Brasília, 28 fev. 1967.

BRASIL. Lei $n^{\circ}$ 6.567, de 24 de setembro de 1978. Dispõe sobre regime especial para exploração e o aproveitamento das substâncias minerais que especifica e dá outras providências. Diário Oficial da União, Brasília, 26 set. 1978.

BRASIL. Lei $n^{\circ}$ 6.938, de 31 de agosto de 1981. Dispõe sobre a Política Nacional do Meio Ambiente, seus fins e mecanismos de formulação e aplicação, e dá outras providências. Diário Oficial da União, Brasília, Seção I, 2 set. I98I.

BRASIL. Lei $n^{\circ}$ 7.347, de 24 de julho de 1985. Disciplina a ação civil pública de responsabilidade por danos causados ao meio-ambiente, ao consumidor, a bens e direitos de valor artístico, estético, histórico, turístico e paisagístico (vetado) e dá outras providências. Diário Oficial da União, Brasília, Seção I, 25 jul. I985.

BRASIL. Instrução Normativa $n^{\circ} 1$, de 24 de agosto de 2012. Ministério da Integração Nacional. Gabinete do ministro. Estabelece procedimentos e critérios para a decretação de situação de emergência ou estado de calamidade pública pelos Municípios, Estados e pelo Distrito Federal, e para o reconhecimento federal das situações de anormalidade decretadas pelos entes federativos e dá outras providências. Diário Oficial da União, Brasília, n I69, Seção I, 30 ago. 20I2, p. 30.

BRASIL. Lei $n^{\circ}$ 13.140, de 26 de junho de 2015. Dispõe sobre a mediação entre particulares como meio de solução de controvérsias e sobre a autocomposição de conflitos no âmbito da administração pública; altera a Lei nffl 9.469, de Io de julho de I997, e o Decreto nffl 70.235, de 6 de março de I972; e revoga o \2 fffl do art. 6ffl da Lei nffl 9.469, de Io de julho de I997. Diário Oficial da União, Brasília, Seção I, 29 jun. 2015, p. 4.

BRASIL. Constituição Federal (I988). Constituição da República Federativa Do Brasil. Texto constitucional promulgado em 5 de outubro de I988, com as alterações determinadas pelas Emendas Constitucionais de Revisão nos i a 6/94, pelas Emendas Constitucionais nos I/92 a 99/20I7. Brasília: Senado Federal, Coordenação de Edições Técnicas, 2017.

BRASIL. Decreto $n^{\circ}$ 9.406, de 12 de junho de 2018 (Regulamento do Código de Mineração). 
Regulamenta o Decreto-Lei $n^{\circ} 227$, de 28 de fevereiro de I967, a Lei $n^{\circ} 6.567$, de 24 de setembro de 1978 , a Lei ${ }^{\circ} 7.805$, de 18 de julho de 1989 , e a Lei $n^{\circ} 13.575$, de 26 de dezembro de 20I7. Diário Oficial da União, Brasília, ı3 jun. 2018.

BRASIL. Lei $n^{\circ}$ 13.844, de 18 de junho de 2019. Estabelece a organização básica dos órgãos da Presidência da República e dos Ministérios; altera as Leis nos I3.334, de I3 de setembro de 20I6, 9.069, de 29 de junho de I995, II.457, de I6 de março de 2007 , 9.984, de I7 de julho de 2000, 9.433, de 8 de janeiro de I997, 8.00I, de I3 de março de I990, II.952, de 25 de junho de 2009 , I0.559, de I3 de novembro de 2002 , II.440, de 29 de dezembro de 2006, 9.613, de 3 de março de I998, II.473, de Io de maio de 2007 , e I3.346, de Io de outubro de 20I6; e revoga dispositivos das Leis nos I0.233, de 5 de junho de 2001 , e II.284, de 2 de março de 2006 , e a Lei $n^{\circ}$ I3.502, de I ${ }^{\circ}$ de novembro de 20I7. Diário Oficial da União, Brasília, Seção I, I8. Set. 20I9, Edição extra, p. 4.

BUCK, Philip. Disaster: Mandated Definitions, Local Knowledge And Complexity. In: PERRY, Ronald W.; QUARANTELLI, E. L. What is a Disaster? New Answers to Old Questions. Colorado Springs: Xlibris, 2005. p. I73-200.

CAMARGO, Ricardo Antônio Lucas. Direito econômico: aplicação e eficácia. Porto Alegre: Sergio Antonio Fabris Ed., 200I.

CAMARGO, Ricardo Antonio Lucas. "Custos dos direitos" e reforma do estado. Porto Alegre: Sergio Antonio Fabris, 2008.

CAMARGO, Ricardo Antônio Lucas. Verbete Ideologia (II). In: FUNDAÇÃO Brasileira de Direito Econômico. Novo dicionário de direito econômico. Porto Alegre: Sergio Antonio Fabris, 2010.

CAMARGO, Ricardo Antônio Lucas. Curso elementar de direito econômico. Porto Alegre: Núria Fabris, 20I4.

CAMARGO, Ricardo Lucas. Constituição econômica, conflitos de interesses e conceitos. Porto Alegre: Sergio Antonio Fabris Ed., 20I5.

CAMARGO, Ricardo Antônio Lucas. Fundamentos constitucionais da política econômica. Porto Alegre: Sergio Antonio Fabris Ed., 2016.

CLARK, Giovani; CORREA, Leonardo Alves; NASCIMENTO, Samuel Pontes do. Constituição econômica bloqueada: impasses e alternativas. Teresinha: EDUFPI, 2020.

COSTA, Rafael Ferreira. A Solução Concertada ao Desastre do Rio Doce (Caso Samarco): O Equilíbrio entre o Interesse Nacional na Atividade da Mineração e a Defesa do Meio Ambiente. No prelo. 202I.

CPRM - Serviço Geológico do Brasil. Monitoramento Especial da Bacia do Rio Doce. Relatório I. Belo Horizonte, 20I5. Disponível em http://www.cprm.gov.br/publique/ media/hidrologia/eventos_criticos/riodoce_relatorioi.pdf. Acesso em: 27 abr. 2017.

DIDIER JR., Fredie; ZANETI JUNIOR, Hermes. Curso de direito processual civil: processo coletivo. I2. ed. Salvador: Editora Juspodivm, 20I8. v. 4.

DINIZ, Maiana. Rompimento liberou 62 milhões de metros cúbicos de rejeitos, diz 
mineradora. Agência Brasil, Brasília, 6 nov. 2015. Disponível em: http://agenciabrasil. ebc.com.br/geral/noticia/20I5-II/rompimento-liberou-62-milhoes-de-metroscubicos-de-rejeitos-diz-mineradora. Acesso em: 29 abr 2017.

ESPINDOLA, Haruf Salmen; NODARI, Eunice Suely; SANTOS, Mauro Augusto dos. Rio Doce: riscos e incertezas a partir do desastre de Mariana (MG). Revista Brasileira de História, São Paulo, v. 39, n. 8I, maio/ago., 20I9. p. I4I-I62.

FREIRE, William. Código de mineração anotado. 4. ed. rev., atual. e ampl. Belo Horizonte: Mandamentos, 2009.

GI-MG. Novos integrantes de força tarefa do MPMG que apura desastre de Mariana se reúnem em BH. G1-MG. Belo Horizonte, I2/6/20ı6. Disponível em https://gi.globo. $\mathrm{com} / \mathrm{minas}$-gerais/desastre-ambiental-em-mariana/noticia/novos-integrantes-deforca-tarefa-do-mpmg-que-apura-desastre-de-mariana-se-reunem-em-bh.ghtml. Acesso em:22 dez 2017.

GILBERT, Claude. Studying disaster: Changes in the main conceptual tools. In: QUARANTELLI, E. L. What is a Disaster? Perspectives on the question. London: Routledge, I998. p. 3-II.

HESSE, Konrad. A força normativa da Constituição. Porto Alegre: Sergio Antonio Fabris Editor, I99I.

IBAMA - Instituto Brasileiro do Meio Ambiente e dos Recursos Naturais Renováveis. Laudo Técnico Preliminar: Impactos ambientais decorrentes do desastre envolvendo o rompimento da barragem de Fundão, em Mariana, Minas Gerais. 2. dez. 2018. Disponível em https://www.ibama.gov.br/phocadownload/barragemdefundao/ laudos/laudo_tecnico_preliminar_Ibama.pdf. Acesso em: 8 jan. 20 I9.

LOSEKANN, Cristiana; MILANEZ, Bruno. A emenda e o soneto: notas sobre os sentidos da participação no TAC de Governança. Versos - Textos para Discussão PoEMAS, Rompimento da Barragem de Fundão, Dossiê TAC Governança, v. 2, n. I, 2018.

MELLO, Marcos Bernardes de. Teoria do fato jurídico - Plano da validade. 8. Ed., São Paulo: Saraiva, 2008, p. 39 apud NERY JUNIOR, Nelson. Soluções práticas de direito: arbitragem e processo coletivo. 2. ed. rev., atual. e ampl. São Paulo: Editora Revista dos Tribunais, 20I4. v. 5, p. 50I-2. (Soluções práticas de direito.)

MME - Ministério das Minas e Energia. Secretaria Geral. Secretaria de Tecnologia. Programa de Tecnologia Mineral. Brasília: MME, I984.

MPES - Ministério Público do Estado do Espírito Santo. Termo de Compromisso Socioambiental Preliminar Firmado entre Ministério Público Federal, Ministério Público do Estado do Espírito Santo, Ministério Público do Trabalho do Estado do Espírito Santo e Samarco Mineração S/A. Vitória, I5 de novembro de 20I5. Disponível em https://www. mpes.mp.br/Arquivos/Anexos/cc305cc3-baf7-4974-8926-cae4aaf666oo.pdf. Acesso em: 26 mar. 2018.

MPF - Ministério Público Federal. Termo de Ajustamento Preliminar firmado entre Ministério Público Federal, Samarco Mineração S/ A, Vale S/A e BHP Billiton Brasil Ltda. 
Belo Horizonte, I8 de janeiro de 20I7. Disponível em: http://www.mpf.mp.br/mg/ sala-de-imprensa/docs/termo-de-acordo-preliminar-caso-samarco. Acesso em: 28 mar. 2018.

MPF - Ministério Público Federal; MPMG - Ministério Público do Estado de Minas Gerais. Termo Aditivo ao Termo de Ajustamento Preliminar Firmado entre Ministério Público Federal, Samarco Mineração S. A., Vale S/A e BHP Billiton Brasil Ltda. Belo Horizonte, 16 de novembro de 2017 . Disponível em: http://www.mpf.mp.br/para-ocidadao/caso-mariana/documentos/aditivo-tap. Acesso em: 2I mar. 2018.

MPF - Ministério Público Federal et al. Termo de Ajustamento De Conduta ("Acordo") firmado entre Ministério Público Federal; Ministério Público do Estado De Minas Gerais; Defensoria Pública, et al., Samarco Mineração S. A., Vale S/A e BHP Billiton Brasil Ltda. Belo Horizonte, 25 de junho de 20r8. Disponível em: http://www.mpf.mp.br/grandescasos/caso-samarco/documentos/tac-governanca. Acesso em: 21 mar. 2018.

MPMG - Ministério Público do Estado de Minas Gerais; CAOMA - Centro de Apoio Operacional das Promotorias de Justiça da Defesa do Meio Ambiente, do Patrimônio Histórico e Cultural e da Habitação e Urbanismo. Caso Samarco: Relatório de Atividades da Força-Tarefa do MPMG. [s.1.], 20I6. p. 9. Disponível em: https://www.mpmg. mp.br/lumis/portal/file/fileDownload.jsp?fileId=8A9ICFA958I98AI50I58IC2DD3D C437B. Acesso em: I5 jul. 2017.

NERY JUNIOR, Nelson. Soluções práticas de direito: arbitragem e processo coletivo. 2. ed. rev., atual. e ampl. São Paulo: Editora Revista dos Tribunais, 20I4. v. 5. (Soluções práticas de direito.)

PONTES DE MIRANDA, Francisco Cavalcanti. Tratado de Direito Privado - Parte geral.. São Paulo: Revista dos Tribunais, 20I2. Tomo IV: Validade. Nulidade. Anulabilidade.

SALINAS, Natasha Schmitt Caccia. Caso Samarco: implicações jurídicas, econômicas e sociais do maior desastre ambiental do Brasil. In: FALCÃO, Joaquim; PORTO, Antônio José Maristrello; ALCÂNTARA, Paulo Augusto Franco de (Org.). Depois da lama: Mariana e as consequências de um desastre construído. Belo Horizonte, MG: Letramento, 2016.

SAMARCO MINERAÇÃO S/A. Rompimento de Fundão. Entenda o Rompimento. Samarco Mineração, 20I6. Disponível em https://www.samarco.com/rompimento-defundao. Acesso em:I8 ago. 20I7.

SANDRONI, Paulo. Verbete Schumpeter e a Destruição Criadora. In: DICIONÁRIO de economia do sec. XXI [recurso eletrônico]. Rio de Janeiro: Record, 20i6. n. p.

SCHUMPETER, Joseph Alois. Capitalismo, Socialismo e Democracia. São Paulo: Editora da Unesp, 2017.

SERRA, Cristina. Tragédia em Mariana: a história do maior desastre ambiental do Brasil. Rio de Janeiro: Record, 2018.

SJMG - Seção Judiciária de Minas Gerais. Justiça Federal. I2. Vara Cível/Agrária de Minas Gerais. Sentença Conjunta nos Autos Principais 0023863-07.2016.4.01.3800 e o069758-61.2015.4.01.3400. 8 ago. 20I8. Disponível em: https://apublica.org/wp- 
content/uploads/20I8/o9/SENTENC\%CC\%A7A-CONJUNTA-HOMOLOGACAOJUDICIAL-08-DE-AGOSTO-DE-2018-ıo.pdf. Acesso em: I4 nov. 2018.

SOUZA, Tatiana R.; CARNEIRO, Karine G. O papel das Assessorias Técnicas no TAC Governança. Versos - Textos para Discussão - PoEMAS, Rompimento da Barragem de Fundão, Dossiê TAC Governança, v. 2, n. I, 2018.

SOUZA, Washington Peluso Albino de. Teoria da constituição econômica. Belo Horizonte: Del Rey, 2002.

SOUZA, Washington Peluso Albino de. Primeiras linhas de direito econômico. 6. ed. 2. tir. São Paulo: Ltr, 2005a.

SOUZA, Washington Peluso Albino de. O Estatuto da Cidade e o Planejamento. Revista da Faculdade de Direito da Universidade Federal de Minas Gerais, Belo Horizonte, v. 46, p. 343-36r, jan.-jun. 2005b.

SOUZA, Washington Peluso Albino de. O conceito e objeto do direito econômico. In: SOUZA, Washington Peluso Albino de, CLARK, Giovani (Coord.). Direito econômico e a ação econômica estatal na pós-modernidade. São Paulo: LTr, 201 I.

WANDERLEY, Luiz Jardim et al. Desastre da SAMARCO/VALE/BHP no Vale do Rio Doce: Aspectos Econômicos, Políticos e Socioambientais. In: Ciência e Cultura. vol.68, n.3, 2016. p. 30-5. 2016. 